\title{
HIDDEN COSTS OF QUALITY: MEASUREMENT \& ANALYSIS
}

\author{
Sailaja $\mathrm{A}^{1}, \mathrm{P} \mathrm{C} \mathrm{Basak}^{2}$ and K G Viswanadhan ${ }^{3}$ \\ ${ }^{1}$ School of Management, Indira Gandhi National Open University (IGNOU), New Delhi, \\ India, ${ }^{2}$ Former Professor of Management, Indira Gandhi National Open University \\ (IGNOU), \\ ${ }^{3}$ Principal, College of Engineering \& Management, Punnapra, Kerala , India
}

\begin{abstract}
Quality is the assurance of adherence to the customer specifications and it is a measure of excellence or a state of being free from defects, deficiencies and significant variation from standards. Customer specification of the product can be met by strictly adhering to the quality control measures in the production process and can be ensured in a cost effective manner only if the quality of each and every process in the organization is well defined and ensured without any lapses. Every activity in the supply chain line to be critically verified to identify the quality deviations incurring additional expense or loss to the organization. This is in line with the continual improvement principle of TQM philosophy. The cost of quality management system acts as the most significant tool in measuring, monitoring, controlling and decision making activities in a firm which aims on business excellence.
\end{abstract}

\section{KEY WORDS}

Quality Cost, Hidden costs, Opportunity costs, Pareto Diagram, Quality Management System.

\section{INTRODUCTION}

A strong control over the management of utilization of resources of all categories in a manufacturing process becomes the demand of the day due to the high competition among the players of the present market. The resources-man, material, machine and time-to be utilized in a most cost effective manner to ensure the profitability of any business and at the same time no compromise in the quality is permissible. This is the highly competitive globalized market scenario today.

Hence management and financial accounting have an important role in the measurement and control of the components of manufacturing costs. On the other hand quality improvement programs for attaining continual improvements have become essential to any business organization to thrive forward profitably with enhancement in its customer base. The question is how to achieve both these objective without losing organizational interests. Cost of quality has evolved as the answer to this question. Cost of quality analysis is considered as one of the most effective management tool for gathering and analyzing the expenses in maintaining quality in a manufacturing process and also identifies the non-value added expenses. Quality improvement 
programs can be critically analyzed using quality costing techniques to check the merit of the program. This helps the management to identify the areas for improvement in quality as well in reducing wastages and hence ensure profitability.

Cost of quality or quality costs in a broader sense is the expenses incurred by an organization in achieving and maintaining good quality as well as in managing poor quality throughout its line of operations with an aim to attain highest level of customer satisfaction. The cost of quality analysis triggers changes and provide proof why changes should be made. The need to improve the financial position of an organization directly correlates with the process of making quality improvements. Cost of poor quality will tend to zero, if every activities are performed well in time.

Many models of quality cost analysis have been evolved since the inception of this concept by the quality guru Dr. Joseph Juran in 1950. The classical PAF model by Feigenbaum (1956) which distinguishes quality costs into Prevention-Appraisal-Failure categories, Process Cost Model by Marsh and Ross (1976) classifying quality costs into cost of conformance and non-conformance in the manufacturing processes, Opportunity Cost Model by Sandoval- Chavez (1998) with the addition of opportunity losses to the other traditional models and the ABC-COQ integrated model by Tsai (1998) are the prominent models among them. Many more dimensions have been added to the quality cost analysis by researchers like Steve Elridge (2006) who has added knowledge management concept to quality, Sower etal (2007) who has analyzed the quality cost as a measure of system maturity with the analysis of the relationship between quality and quality costs and Ali Uyar (2008) and Zulnadi yakup (2010) who have analyzed quality cost as money invested and money lost.

The difficulties in implementation of a COQ system (Ming Tsung-2010), insufficiency in reports (Lee Hoon Tye-2011), in capability of addressing intangible costs (Assissi Jaffer-2010) and non synergy with TQM concepts (Aviora Aspinwal-2009) were addressed by many researchers.

Technological advancements in management were also effectively utilized by many researchers in analyzing quality cost. Behdad Kiani etal (2009) designed a model for analyzing the influence of costs of quality through a system dynamics approach. Mahanty. B (2012) developed a system dynamics model of quality cost in a manufacturing firm with the new features like time dependent deterioration process, formation of quality perception and market reaction. Arman Sadreddin etal (2014) developed a Cost of Quality (COQ) model for the procurement process of the construction industry to establish a general course of action for minimizing quality costs which take into account not only the internal quality costs within the company, but also the costs of its suppliers. Several different policies were designed and their effects on quality costs investigated through System Dynamics (SD) simulation.

Mathematical modeling was effectively used by NVR Naidu (2008) for analyzing quality cost categories. R K Sharma et al (2007) successfully applied a fuzzy approach to elicit expert opinion regarding the importance of cost items. The information so obtained after fuzzy synthesis is used to set up priority with respect to the processes which can provide necessary help to managers/ practitioners to invest efforts in reduction of cost of non-conformances (CONC) and optimal allocation of resources. Liang-Hsuan Chen, Ming-Chu Weng, (2002) proposed a fuzzy approaches to evaluate quality improvement alternatives because of its fuzzy nature. An evidence fusion technique, namely Choquet fuzzy integral, is employed to aggregate the quality cost 
information. Quality cost improvement model for analyzing conflicting goals using fuzzy sets was presented by Wang, Ming-Chu et al (2010).

Lin Zhang et al (2010) developed an extended Quality Function Deployment (QFD) approach to assess quality cost of packaging machinery from technical perspectives. Evaluation criteria for quality assurance cost, quality loss cost and comprehensive technical requirements are introduced for analyzing technical requirements that transform from customer needs and AHP is used to calculate and normalize different quality requirement weights.

The behavioral patterns of various cost categories were studied by Chopra eta (2011) and Sailaja et al (2014) using correlation and regression analysis.

Shephered (2002) made an effective approach to the identification and measurement of quality failure costs can be integrated into a balanced score card.

But in spite of the over helming interest shown by the academic community in COQ studies, the industrial experts all over the world is still hesitant to utilize this tool in a fully fledged mode, as apparent from the empirical studies conducted worldwide in this regard.

Cost of quality management study from Turkish marble industry by Ozgur Akkoyun and Huseyin Ankara (2009), Survey regarding quality cost in Romanian service industries by Mariana Glavan et al (2009), Cost of quality practices among Indian industries by T Nath (2003), Aravind Chopra and Dixit Garg(2012) and Paramjit Kaur (2009) , An empirical study of quality cost system implementation in Brazilian tool manufacturing machinery by Felipe ARAÚJO CALARGE(2007), Cost of quality studies in Malaysia (Kanapathy \& M Rasamanie2011,Mukhtar che Ali- 2010), Quality costing reporting studies in Australia by Judi Oliver and Wen Qu (1999), Analytical study of cost of quality of construction projects in Dubai (Hisham M.E. Abdelsalam-2009), cost of quality practices in Spain (Oriol Amat and John Blake-1993), Quality management through ISO certification and quality costs reporting studies in Bahraini companies (Sayed Ramadhan-2005) are few among them.

These studies shows that the industrial application of COQ methods are still limited to the traditional PAF model even though the strengths and capabilities of latest models in overcoming the limitations of PAF method is well appreciated by academic community. In most of the cases only direct and easily traceable costs only are gathered (Schiffaura- 2006).

\subsection{Significance of the study}

Many researchers were pointed out the requirement of analyzing all elements of quality costs to make optimal decisions that leads to competitive advantages in the highly customer driven modern market (Yang-2008). Bramford (2006) emphasize the quality cost analysis can be used as an effective tool for management only when all quality cost elements are captured. Improvements in the conventional model with the incorporation of additional cost categories were made by many researchers. Modaress \& Ansari (1987) incorporated two additional dimensions viz, cost of quality design and cost of inefficient utilization. The losses incurred due to the internal inefficiencies were studied by Dahlgaard etal (1992). Sandoval-Chavez (1998) presented a modified COQ model with the inclusion of three elements -under utilization of installed capacity, inadequate material handling and poor service delivery. Giakatis (2000) analyzed the losses 
incurred against manufacturing and design losses. Intangible costs like loss to society is analyzed by Teevaraprug(2004).Gary Cockins (2006) has explained the difficulty in measuring hidden costs. Yang (2008) attempted to quantify lost sales as estimated hidden cost. Soo-Jin Chea (2011) presented an action research study of tracking hidden quality costs in a manufacturing process with a focus on the resistance of employees towards implementation of COQ system. The significance of tracking and gathering hidden quality cost data were explained by Kume (1985), Sandoval (1998), Giakatis etal(2010), Johannes Freiesleben and Suresh Krishna(2010) .

Even though these studies were well appreciated by the quality practitioners, not much practical studies found available in the literature with comprehensive data collection and analysis of all costs including hidden costs incurred against all quality improvement activities in the organization.

The practical studies in the case of hidden costs of quality are limited to hidden failure costs (Suresh Krishna-2006) and hidden costs in the manufacturing process (SooJin-Chea-2011). Not many studies are in place on opportunity costs also. Any activity which is not performed well in right time always incurs a loss to the organization. Opportunity costs are the losses incurred against a missed out opportunity of doing things right at first time. It is actually the measure of internal inefficiencies and its analysis will provide immense opportunities for improvement.

Hence an attempt is made in this research to unveil all hidden quality costs including opportunity costs right from the customer requirement analysis to after delivery support, in a manufacturing firm. In the current era, the analysis of each individual stage in the supply chain ranging from raw material acquisition to final delivery of the product is equally important (Ashish J. Deshmukh.and Hari Vasudevan 2014).

\section{RESEARCH OBJECTIVE}

The objective of this study is to identify measure and quantify all the hidden elements -direct, indirect and invisible elements of quality costs in all functional activities in the organization under study. Further the importance of such an analysis is ascertained by quantifying the impacts of hidden costs on the overall quality cost as well as on the organizational bottom line.

\subsection{Methodology}

The following methodology was adapted in this study:

1. Identification of all processes and quality cost elements in all corresponding activities, Comprehensive data collection and quantification, Grouping in to direct and hidden Cost of Quality.

2. Analysis of impact of hidden COQ on total quality cost and also on organizational bottom line.

3. Comparison of traditional COQ system with enhanced COQ with hidden costs included. Personal interviews and discussions with the employees in each section were carried out to list out all processes, its input, output and control process as per the process cost model and all the activities in each process in the supply chain line is identified. Every activity is then analyzed critically to identify the quality lapses in each, which leads to an additional expense or loss to the organization. The missed out opportunities for improvement also listed out. The additional 
resources utilized in each of this instances are systematically identified and quantified using the records like log books, route cards, registers, time study, personal interviews etc. to get the cost incurred in each. Then these cost elements are classified into direct and indirect costs as per the categorization in Figure.1. Further detailed comparative analysis is carried out between them. Finally the impact of indirect and hidden quality cost elements on the overall quality cost and to the organizational bottom line are analyzed.

Total Cost of Quality

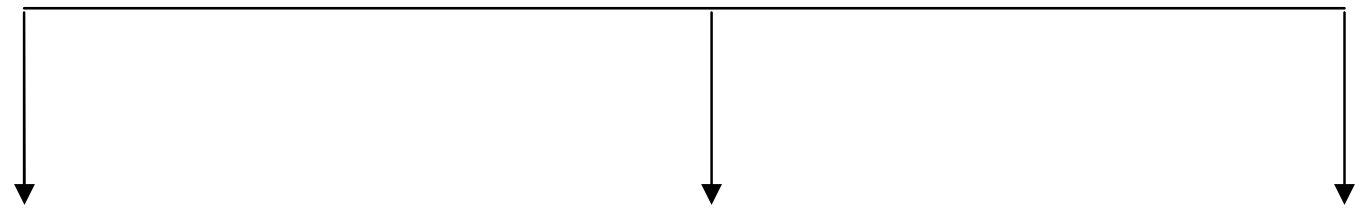

Cost of Conformance (COC)

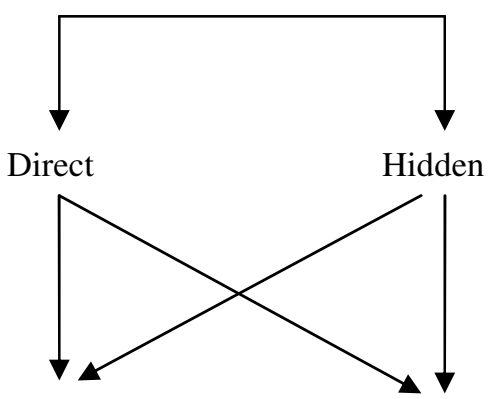

PC
Cost of Non Conformance (CONC)

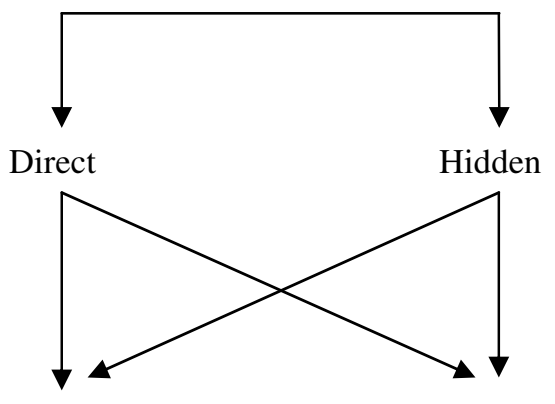

IFC

EFC

(PC-Prevention Costs, AC- Appraisal Costs, IFC- Internal Failure Costs, EFC- External Failure Costs)

Figure 1. Categorization of quality cost elements

\section{DATA COLLECTION AND CATEGORIZATION}

The research has been carried out in a firm under electronic industry engaged in the manufacturing of electronic equipments which is already having ISO 9001:2008 certification. The PAF model of quality costing was already in practice in this firm with emphasis only on traditional P-A-F elements of quality costs which are easily and directly measurable.

During this study, a comprehensive data collection strategy has been adopted for gathering information on various quality cost elements in each activity. For this, the Process Cost Model approach has been adopted, where in each functional area is treated as a set of processes with definite input, output and control processes. Each process is critically analyzed to gather maximum information on quality deviation against all the activities which make the process complete. Then the cost incurred including indirect and hidden against these quality deviations are quantified using the records of additional resource utilization in this regard. Lost opportunities in each process also identified and corresponding cost data captured and quantified.

The traditional elements of costs of conformance and non-conformance identified and analyzed in this research are listed in Table-1. 
International Journal of Managing Value and Supply Chains (IJMVSC) Vol. 6, No. 2, June 2015

Table.1 - Direct Quality Cost elements

\begin{tabular}{|c|c|c|c|}
\hline \multicolumn{2}{|c|}{ Direct Conformance Costs(COC-D) } & \multicolumn{2}{|c|}{ Direct Non conformance Costs(CONC-D) } \\
\hline $\begin{array}{l}\text { Prevention Costs (PC- } \\
\text { D) }\end{array}$ & $\begin{array}{l}\text { Appraisal Costs (AC- } \\
\text { D) }\end{array}$ & $\begin{array}{l}\text { Internal Failure Costs } \\
\text { (IFC-D) }\end{array}$ & $\begin{array}{l}\text { External Failure } \\
\text { Costs (EFC-D) }\end{array}$ \\
\hline $\begin{array}{l}\text { Cost of maintenance of } \\
\text { ISO certification }\end{array}$ & Raw material inspection & Scrap\wastages & $\begin{array}{l}\text { Trouble shooting } \\
\text { of field failures }\end{array}$ \\
\hline $\begin{array}{l}\text { Training cost on quality } \\
\text { standards, theories and } \\
\text { practices }\end{array}$ & $\begin{array}{l}\text { In-Process inspection- } \\
\text { sub assemblies and } \\
\text { assemblies }\end{array}$ & $\begin{array}{l}\text { Internal Trouble } \\
\text { Shooting - Repair, Re- } \\
\text { test etc. }\end{array}$ & $\begin{array}{l}\text { Expenditure on } \\
\text { customer service } \\
\text { dept. for support } \\
\text { calls from } \\
\text { customers }\end{array}$ \\
\hline $\begin{array}{l}\text { Cost on administration } \\
\text { of quality issues }\end{array}$ & $\begin{array}{l}\text { Final tests after } \\
\text { integration of sub } \\
\text { assemblies and modules }\end{array}$ & $\begin{array}{l}\text { Rejections and rejection } \\
\text { analysis }\end{array}$ & $\begin{array}{l}\text { Repair of } \\
\text { defective parts }\end{array}$ \\
\hline $\begin{array}{l}\text { Cost on vendor quality } \\
\text { assurance }\end{array}$ & $\begin{array}{l}\text { Pre- dispatch tests by } \\
\text { quality assurance } \\
\text { department }\end{array}$ & Re work & $\begin{array}{l}\text { Replacement of } \\
\text { defective parts }\end{array}$ \\
\hline $\begin{array}{l}\text { Preventive maintenance } \\
\text { cost of equipments \& } \\
\text { machineries }\end{array}$ & $\begin{array}{l}\text { Cost on internal as well } \\
\text { as customer audits }\end{array}$ & $\begin{array}{l}\text { Excess material drawn } \\
\text { against rejections, scraps } \\
\text { etc. }\end{array}$ & Product recalls. \\
\hline \multirow{2}{*}{$\begin{array}{l}\text { Preventive maintenance } \\
\text { of test jigs \& tools }\end{array}$} & & $\begin{array}{l}\text { Interest on non moving } \\
\text { inventory }\end{array}$ & \\
\hline & & Machine break down & \\
\hline $\begin{array}{l}\text { Cost of calibration of } \\
\text { equipments }\end{array}$ & & $\begin{array}{l}\text { Materials written off due } \\
\text { to product design } \\
\text { changes }\end{array}$ & \\
\hline
\end{tabular}

The hidden quality cost elements are identified by extensive information collection by interviews, log books, records and registers kept in various activity centers with entry of time study, time cards, machine logbooks, complaint log books, attendance cards, minutes of meetings etc. and the cost elements identified in this study are listed in Table 2.

Table-2- Hidden quality cost elements

\begin{tabular}{|l|l|l|l|}
\hline \multicolumn{2}{|c|}{ Hidden Conformance Costs(COC-H) } & \multicolumn{2}{c|}{ Hidden Non conformance Costs(CONC-H) } \\
\hline $\begin{array}{c}\text { Prevention Costs } \\
\text { (PC-H) }\end{array}$ & \multicolumn{1}{|c|}{$\begin{array}{c}\text { Appraisal Costs } \\
\text { (AC-H) }\end{array}$} & Internal failure Costs (IFC-H) & $\begin{array}{l}\text { External Failure } \\
\text { Costs (EFC-H) }\end{array}$ \\
\hline $\begin{array}{l}\text { Customer } \\
\text { requirement } \\
\text { review }\end{array}$ & $\begin{array}{l}\text { Process audits at } \\
\text { vendor premises }\end{array}$ & Engineering or design mistakes & Warranty claims \\
\hline $\begin{array}{l}\text { Engineering } \\
\text { design reviews }\end{array}$ & Customer audits & Billing errors and rework on bills & $\begin{array}{l}\text { Man power for } \\
\text { field assistance } \\
\text { on complaints }\end{array}$ \\
\hline
\end{tabular}


International Journal of Managing Value and Supply Chains (IJMVSC) Vol. 6, No. 2, June 2015

\begin{tabular}{|l|l|l|l|}
\hline Process validation & $\begin{array}{l}\text { Document procedures for raw } \\
\text { material rejections }\end{array}$ & $\begin{array}{l}\text { Emergency } \\
\text { dispatches }\end{array}$ \\
\hline & Production Planning errors & \\
\hline & & $\begin{array}{l}\text { Raw material planning errors lead } \\
\text { to extra raw material cost }\end{array}$ & \\
\hline
\end{tabular}

Similarly lost opportunities due to incapability of the system as well as inefficiencies are also listed out in each process and measurement techniques are devised by extensive data collection against each element identified after rigorous discussions with the authorities concerned. The identified Opportunity Cost (OC) elements with details are listed in Table-3.

Table 3: Opportunity Cost elements

\begin{tabular}{|l|l|l|}
\hline 1 & $\begin{array}{l}\text { Under } \\
\text { utilization of } \\
\text { machine } \\
\text { capacity }\end{array}$ & $\begin{array}{l}\text { Utilization below the installed planned capacity of machines due to insufficient } \\
\text { customer orders, balanced quantity of raw materials, consumables or work force as } \\
\text { well as planning inefficiencies. }\end{array}$ \\
\hline 2 & $\begin{array}{l}\text { Loss due to } \\
\text { delayed } \\
\text { payments }\end{array}$ & $\begin{array}{l}\text { Delayed payments to the raw material vendors and loss of mutual trust results in } \\
\text { demand from vendors for advance payments instead of credit purchases. Loss on } \\
\text { account of interest against the lost credit period. }\end{array}$ \\
\hline 3 & $\begin{array}{l}\text { Customs } \\
\text { clearance of } \\
\text { materials }\end{array}$ & $\begin{array}{l}\text { Customs demurrage charges on delayed customs clearance of materials. Also results } \\
\text { in extra documentation, Follow up time etc. }\end{array}$ \\
\hline 4 & $\begin{array}{l}\text { Excess } \\
\text { Financial } \\
\text { charges by } \\
\text { Banks }\end{array}$ & $\begin{array}{l}\text { Penalties imposed by banks against insufficiency of documents for financial } \\
\text { clearances, Losses due to foreign exchange variations due to the absence of forward } \\
\text { contracts etc. }\end{array}$ \\
\hline 5 & $\begin{array}{l}\text { Emergency } \\
\text { Dispatches }\end{array}$ & Extra shipping costs to meet customer urgency and to cop up with delayed dispatches. \\
\hline 6 & $\begin{array}{l}\text { Late } \\
\text { delivery(LD) }\end{array}$ & $\begin{array}{l}\text { Liquidate damages (LD)imposed by customer on late deliveries, part deliveries, delay } \\
\text { in after sale support etc. }\end{array}$ \\
\hline 7 & $\begin{array}{l}\text { Sundry } \\
\text { Debtors }\end{array}$ & $\begin{array}{l}\text { Payment realization delays results in accumulation of sundry debtors and loss of } \\
\text { interest or availability of sufficient fund flow. }\end{array}$ \\
\hline 8 & $\begin{array}{l}\text { Lost sales } \\
\text { Poor performances in product and service leads to customer dissatisfaction which in } \\
\text { turn results in reduction in market share. }\end{array}$ \\
\hline
\end{tabular}




\subsection{DATA ANALYSIS AND DISCUSSIONS}

Based on the data collected, different quality cost elements are grouped into different cost categories and computed for a period of 3 consecutive years as summarized in Table- 4 along with its percentage analysis to annual sales volume as well as to total cost of quality.

Table 4: Comparative analysis of cost categories of quality cost data

\begin{tabular}{|c|c|c|c|c|c|c|c|c|c|c|}
\hline & & \multicolumn{3}{|c|}{$\begin{array}{l}\text { Year 1: Sales Volume- } \\
\text { INR 19076.00 lakhss. }\end{array}$} & \multicolumn{3}{|c|}{$\begin{array}{l}\text { Year 2- Sales Volume } \\
\text { INR 16322.00 lakhss. }\end{array}$} & \multicolumn{3}{|c|}{$\begin{array}{c}\text { Year 3- Sales Volume: INR } \\
10296.75 \text { lakhss. }\end{array}$} \\
\hline & $\begin{array}{c}\text { Cost } \\
\text { Category }\end{array}$ & $\begin{array}{l}\text { Value } \\
\text { (INR- } \\
\text { Lal-hs) }\end{array}$ & $\begin{array}{c}\% \text { to } \\
\text { sales } \\
\text { volume }\end{array}$ & $\begin{array}{l}\% \text { to } \\
\text { total } \\
\mathrm{COQ}\end{array}$ & $\begin{array}{l}\text { Value } \\
\text { (INR- } \\
\text { Lal-hs) }\end{array}$ & $\begin{array}{c}\% \text { to } \\
\text { sales } \\
\text { volume }\end{array}$ & $\begin{array}{l}\% \text { to } \\
\text { total } \\
\mathrm{COQ}\end{array}$ & $\begin{array}{l}\text { Value } \\
\text { (INR- } \\
\text { Lalkhs) }\end{array}$ & $\begin{array}{c}\% \text { to } \\
\text { sales } \\
\text { volume }\end{array}$ & $\begin{array}{l}\% \text { to } \\
\text { total } \\
\text { COQ }\end{array}$ \\
\hline \multirow{4}{*}{$\frac{3}{3}$} & PC-D & 258.04 & $1.35 \%$ & $3.98 \%$ & 296.21 & $1.81 \%$ & $4.25 \%$ & 324.29 & $3.15 \%$ & $4.46 \%$ \\
\hline & $A C-D$ & 380.21 & $1.99 \%$ & $5.86 \%$ & 374.22 & $2.29 \%$ & $5.37 \%$ & 372.32 & $3.62 \%$ & $5.13 \%$ \\
\hline & IFC-D & 947.34 & $4.97 \%$ & $14.60 \%$ & 821.22 & $5.03 \%$ & $11.79 \%$ & 762.11 & $7.40 \%$ & $10.49 \%$ \\
\hline & EFC-D & 110.43 & $0.58 \%$ & $1.70 \%$ & 172.98 & $1.06 \%$ & $2.48 \%$ & 83.82 & $0.81 \%$ & $1.15 \%$ \\
\hline \multicolumn{2}{|c|}{$\begin{array}{l}\text { Total Direct } \\
\text { Costs }\end{array}$} & 1696.03 & $8.89 \%$ & $26.14 \%$ & 1664.63 & $10.20 \%$ & $23.89 \%$ & 1542.54 & $14.98 \%$ & $21.24 \%$ \\
\hline \multirow{4}{*}{ 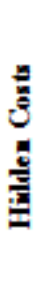 } & PC-H & 6.899 & $0.04 \%$ & $0.11 \%$ & 6.72 & $0.04 \%$ & $0.10 \%$ & 7.32 & $0.07 \%$ & $0.10 \%$ \\
\hline & AC-H & 7.258 & $0.04 \%$ & $0.11 \%$ & 7.31 & $0.04 \%$ & $0.10 \%$ & 8.94 & $0.09 \%$ & $0.12 \%$ \\
\hline & IFC-H & 236.928 & $1.24 \%$ & $3.65 \%$ & 225.62 & $1.38 \%$ & $3.24 \%$ & 209.76 & $2.04 \%$ & $2.89 \%$ \\
\hline & EFC-H & 23.579 & $0.12 \%$ & $0.36 \%$ & 39.32 & $0.24 \%$ & $0.56 \%$ & 16.22 & $0.16 \%$ & $0.22 \%$ \\
\hline \multicolumn{2}{|c|}{$\begin{array}{l}\text { Total Hidden } \\
\text { Costs }\end{array}$} & 274.664 & $1.44 \%$ & $4.23 \%$ & 278.97 & $1.71 \%$ & $4.00 \%$ & 242.24 & $2.35 \%$ & $3.34 \%$ \\
\hline & $\mathrm{OC}$ & 4518.28 & $23.69 \%$ & $69.63 \%$ & 5023.67 & $30.78 \%$ & $72.10 \%$ & 5478.45 & $53.21 \%$ & $75.43 \%$ \\
\hline \multicolumn{2}{|c|}{ Total COQ } & 6488.98 & $34.02 \%$ & & 6967.27 & $42.69 \%$ & & 7263.23 & $70.5 \%$ & \\
\hline
\end{tabular}

The result shows that Cost of quality captured in the traditional systems in the year- 1 is $8.89 \%$ of sales revenue whereas the same in the enhanced system with hidden and opportunity costs included is $34.02 \%$. The total hidden and opportunity costs amounts to $25 \%$ of sales revenue, which is around 3 times higher than the costs based on traditional P-A-F model. The traditional quality cost amounts to $26.14 \%$ of total quality cost, where as total sum of hidden quality cost is $73.86 \%$ of total quality cost, out of which major portion is contributed by the opportunity costs $(69.63 \%)$.

Similar is the case with next two consecutive years under study; where in the total direct costs are $10.20 \% \& 14.98 \%$ of sales turnover and $23.89 \% \& 21.24 \%$ of the total COQ. Here also the opportunity costs are more than $30 \% \& 50 \%$ of sales revenue respectively. When we analyze the 
per category contributions to the total quality costs, opportunity costs shows the major category with more than $70 \%$ contribution as represented in Figure 2, Figure $3 \&$ Figure 4 .This gives a clear picture of the quantum and impacts of hidden quality costs and opportunity losses to the organization.

Figure 2, 3, 4: Category wise contribution to total Quality Cost for Year1, Year2 \& Year 3
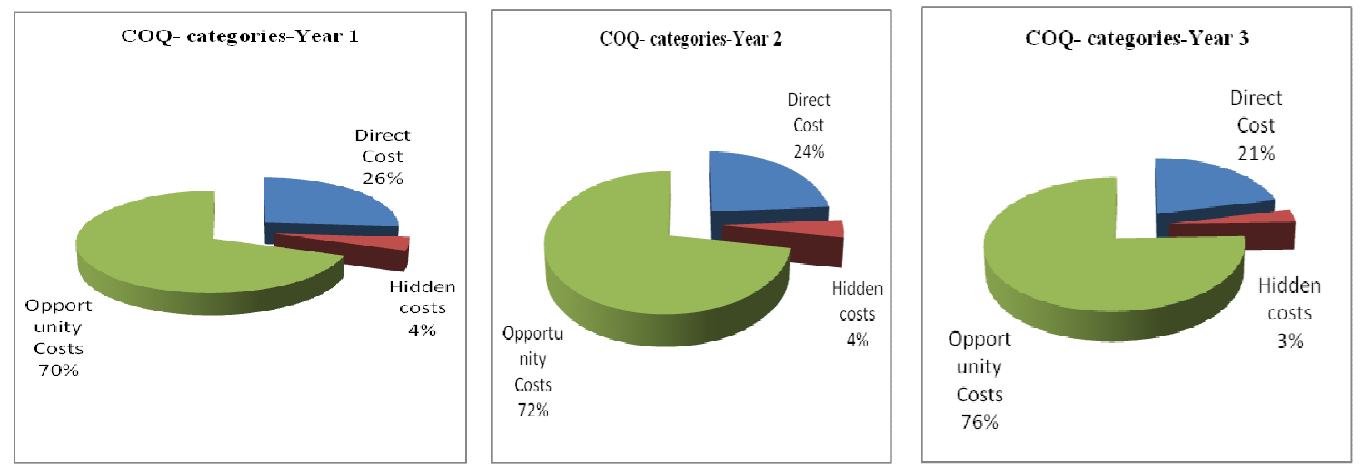

The Pareto analysis of all the identified cost elements also confirms the importance of hidden cost elements. Out of the total 43 quality cost elements identified under various categories, 8 cost elements found contributing to more than $80 \%$ of the total COQ value, out of which first three major contributors are of opportunity cost.

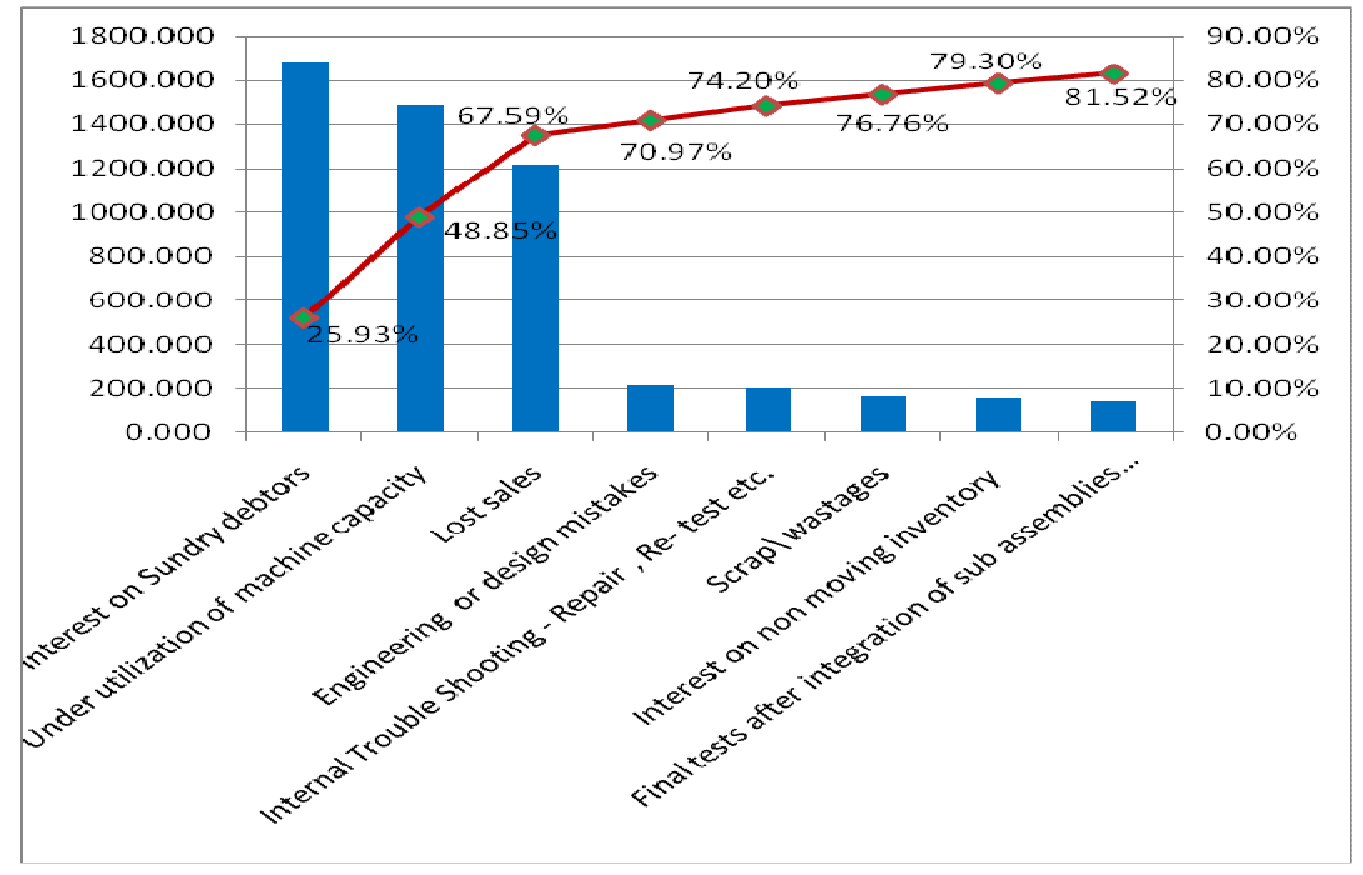

Figure 5: Pareto analysis of the opportunity costs

The Pareto chart shows that $80 \%$ of the quality costs come from $20 \%$ of the causes. The analysis shows that Interest on Sundry debtors $(25.93 \%)$, under utilization of machine capacity $(22.91 \%)$ 
and lost sales (18.74\%), are the major categories of the total quality costs. All these three elements are hidden opportunity cost elements. Figure 5 shows the Pareto analysis of these results.

As per the traditional P-A-F system of quality cost calculation, the firm under study was considered as a healthy organization with cost of quality value within an admissible limit of $10 \%$ of sales turn over in the first year of study. But this study reveals that the actual quality cost of the firm in first year itself is more than $30 \%$ of sales revenue and in the second year it has become $42 \%$ and in third year $70 \%$ which is an alarming situation. This shows the inadequacy of traditional accounting system in capturing the actual quality costs and also the importance of analyzing various hidden quality costs in a firm.

It is also found that the hidden COQ is higher than the net profit of the company. On analysis it is revealed that most of these opportunity costs can be eliminated with awareness of the impact of the lost opportunities and proper planning to eliminate the root causes. The underutilization of machine capacity can be reduced or eliminated with the proper utilization of man power, by capturing more orders by market intelligence and also by effective production planning and scheduling. The lost sales are due to the impact of customer dissatisfaction on quality of supply, delayed delivery and services. Proper and timely payment realization techniques and follow-ups can reduce the losses on account of interest on sundry debtors. Engineering and design mistakes are making many fold effects once it is identified in later stages of production process. This can be avoided by the proper and systematic verification of design requirements in the beginning itself. Most of the hidden costs can be eliminated by ensuring a smooth flow of error free information throughout the production process. This can be ensured with the help of an integrated manufacturing management system. Marketing, Customer engineering, Planning, Purchase, Manufacturing, Quality Assurance, Dispatch and Billing sections can be made integral part of this system. Manual document preparation errors and delays in procedures can be reduced with the usage of this system. Requirement of customer orders to be translated to tables of requirements by marketing department and then key parameters for production process to be identified by manufacturing method section. Subsequently planning dept. can use this data to generate raw material quantities required for production loading for fulfilling the available customer order. Procurement and receipt details of raw materials and consumables also to be updated to the same system from purchase modules. Using this data, manufacturing department can schedule the job work and dispatch information. The costs associated with all the type of manual errors including documentation, loading, scheduling and billing errors can be made zero with the usage of such a system.

This root cause analysis of opportunity costs gives an insight to the opportunities to improve the bottom line of the organization. These losses can be converted to opportunities for increasing profit margin of the firm.

\section{CONCLUSIONS}

In this study, a comprehensive analysis of all cost elements which contributes to the quality of products and services in the supply chain line of a manufacturing firm has been conducted. Apart from the normal prevention-appraisal-failure mode quality cost categories, more in depth analysis of all activities in the whole supply chain is done to track and measure the hidden elements of quality cost including the opportunity cost elements. 
The study findings points out the fact that the hidden cost of quality is more than 3 times higher than the direct quality cost elements in the manufacturing firm and most of these hidden costs can be reduced or even eliminated by proper tracking and understanding the root causes.

This study highlights the inadequacy of traditional cost of quality system in tracking and assessing the overall costs of quality. In order to assess the overall cost of quality, the hidden costs also has to be identified, quantified, measured and analyzed. For tracing the hidden quality costs, it is necessary to move beyond the data produced by the traditional accounting system. This also gives an insight to the huge impact of hidden quality costs to the organizational bottom line and points out the gold mine of improvements. Using this data the company can formulate survival strategies in the highly intensive competitive market scenario.

Future studies in this field are recommended with the study of impacts of hidden elements on overall quality cost and development of a quality cost expert system with inclusion of hidden and opportunity cost elements.

\section{REFERENCES}

[1] Arman Sadreddin, Rema Sawan and Andrea Schiffauerova,(2014) ,"Using System Dynamics Approach to Model Cost of Quality in the Procurement Process of the Construction Industry" , APC Proceedings 2014

[2] Arvaiova, M., Aspinwall, M.E., Walker, S.D, (2009) "An Initial Survey on Cost of Quality Programmes in Telecommunications", the TQM Journal, 21(1), 59-71.

[3] Arvind Chopra ,Dixit Garg,( 2012 ,"Cost of Quality Practices Among Indian Industries", International Journal For Quality Research Vol.6, No. 2.

[4] Arvind Chopra, Dixit Garg, (2011),"Behavior patterns of quality cost categories", The TQM Journal, Vol. 23 Iss: 5, pp.510 - 515

[5] Assizi Jaffer et al, (2010), "Effect of the Quality Costing System on Implementation and Execution of Optimum Quality Management”, International Journal of Business Management, Vol.5, No.8,

[6] Ashish J. Deshmukh.and Hari Vasudevan (2014), "Emerging Supplier Selection Criteria In The Context Of Traditional Vs Green Supply Chain Management”, International Journal of Managing Value and Supply Chains (IJMVSC) Vol.5, No. 1.

[7] Behdad Kiani, Hadi Shirouyehzad, Fahime Khoshsaligheh Bafti, Hamidreza Fouladgar,(2009) "System Dynamics Approach to Analysing the Cost Factors Effects on Cost of Quality", International Journal of Quality \& Reliability Management, Vol. 26 Iss: 7, pp.685 - 698

[8] Biswajit Mahanty, V.N.A. Naikan, And Thuleswar Nath ,( 2012), "System Dynamics Approach for Modeling Cost Of Quality", International Journal of Performability Engineering,Volume 8, Number 6, November 2012 - Paper 4 - pp. 625-634

[9] Dalghaard, J.J., Kristensen, K. \& Kanji, G.K., (1992), "Quality Costs and Total Quality Management", Total Quality Management, 3, pp. $211 \pm 221$.

[10] David R. Bamford, Nicola Land,( 2006), "The Application and Use of the PAF Quality Costing Model Within a Footwear Company", International Journal of Quality \& Reliability Management, Vol. 23 Iss: 3, ,pp.265 - 278

[11] Dr N V R Naidu, ,(2008), “Mathematical Model for Quality Cost Optimization” International Journal Robotics and Computer integrated manufacturing, Vol. 24811 - 815

[12] Eldridge Steve, Balubaid M., (2006), "Using Knowledge Management Approach to Support Quality Costing', International Journal of Quality and Reliability Management, 23(1), 81.

[13] Feigenbaum, A.V., “Total Quality Control”, Harvard Business Review, 34, 1956, pp. 93-101.

[14] Felipe ARAÚJO CALARGE, José RINALDO CRISTAN PAPA, (2007), “An Empirical Study of a Quality Cost System Implementation: Case Study in a Brazilian Machine Tools Manufacturer", Cuadernos de Estudios Empresariales, vol. 17 55-73 
International Journal of Managing Value and Supply Chains (IJMVSC) Vol. 6, No. 2, June 2015

[15] Gary Cockins,( 2006), "Measuring the Cost of Quality for Management" , Quality Progress , September 2006

[16] Georgios Giakatis, Takao Enkawa \& Kazuhiko Washitani , (2001 ),"Hidden Quality Costs and the Distinction Between Quality Cost and Quality Loss", Total Quality Management, Volume 12, Issue 2, , pages 179-190

[17] Georgios Giakatis, Takao Enkawa, Kazuhiko Washitani "Quality Costs and Hidden Quality Costs: Their Importance and Their Environmental Association" APDSI 2000

[18] Hisham M.E. Abdelsalam, Medhat M. Gad, Cost of quality in Dubai,(2009) "An Analytical Case Study of Residential Construction Projects", International Journal of Project Management, Volume 27, Issue 5, July, Pages 501-511

[19] Johannes Freiesleben , (2005),'The Opportunity Costs of Poor Quality”, Quality Assurance Journal, $9,, 3-10$

[20] Judy Oliver and Wen Qu, (1999 ),“Cost of Quality Reporting: Some Australian Evidence”, International Journal of Applied Quality Management,Volume 2, Issue 2, , Pages 233-25

[21] Kanagi Kanapathy ,Murugan Rasamanie, (2011). "Adoption of Cost of Quality Reporting: An Initial Survey of Manufacturing Firms in Malaysia", International Conference on Business and Economics Research, vol.1

[22] Kume, H. "Business Management and Quality Cost: The Japanese View", Quality Progress, May, pp. 13-18.

[23] Lee Hoon Tye et al, (1985)," An Exploratory Study on Cost of Quality Implementation in Malaysia: The Case of Penang Manufacturing Firm", Total Quality Management,Vol.22,No.12, 2011,pp 12991315

[24] Liang-Hsuan Chen, Ming-Chu Weng, (2002),"Using Fuzzy Approaches to Evaluate Quality Improvement Alternative Based on Quality Costs", International Journal of Quality \& Reliability Management, Vol. 19 Iss: 2, pp.122 - 136

[25] Lin Zhang ,Meiyun Zhang ; Yangyu Wu, (2010),“ Quality Cost Analysis of Packaging Machinery Based on Extended QFD Model”, Information Science and Management Engineering (ISME), 2010 International Conference of (Volume:1)

[26] Mariana Glavan, Madalina Dumitu and Michaela Dumitrana, (2009.), "Empirical Study Regarding the Quality Costs in the Romanian Sevice Companies", Quality management in services, Vo.XI, No.26, June 2009.

[27] Ming-Tzong, Wang, Sophia S.-C. Wang, Simon W.-C. Wang and Alex S.-M. Wang , (2010 ), “An Introduction of COQ Models and Their Applications' , Proceedings of the 2010 International Conference on Engineering, Project, and Production Management,

[28] Modarress, B. \& Ansari, A., (1985) "Two Mew Dimensions in the Cost of Quality", International Journal of Quality \& Reliability Management, 4, pp. 9-20.

[29] Mukhtar Che Ali, (2010), "Development of Quantitative Quality Cost Matrix for Malaysian Construction Quality Management System", Doctoral thesis, June.

[30] Oriol Amat \& John Blake,( 1993), "Control of the Cost of Quality Management: A Review of Current Practice in Spain", Economic working paper 49,

[31] Ozgur Akkoyun and Huseyin Ankara, (2009),"Cost of Quality Management: An Empirical Study From Turkish Marble Industry", Scientific Research and Essay Vol.4 (11), pp. 1275-1285.

[32] Parmjit Kaur, (2009), "Current Cost of Quality Management Practices in India in the Era of Globalization: An Empirical Study of Selected Companies", Decision, Vol. 36, No.1, April,

[33] Rajiv Kumar Sharma, Dinesh Kumar, Pradeep Kumar, (2007),"A framework to Implement QCS Through Process Cost Modeling", The TQM Magazine, Vol. 19 Iss: 1, , pp.18 - 36

[34] Sailaja A, K.G. Viswanadhan and P.C. Basak, (2014), "Analysis of Economics of Quality in Manufacturing Industries", International Journal for Quality Research 8(1), 121-138.

[35] Sandoval-Chavez, D.A. and Beruvides, M.G., (1998), "Using Opportunity Costs to Determine the Cost of Quality: A Case Study in a Continuous-Process Industry", The Engineering Economist, Vol. 43 No. 2, pp. 107-24. 
International Journal of Managing Value and Supply Chains (IJMVSC) Vol. 6, No. 2, June 2015

[36] Sayel Ramadhan, (2005), "Quality Management Through ISO Certification And Quality Costs Reporting: A Study Of Bahraini Companies", International Business \& Economics Research Journal - September Volume 4, Number 9

[37] Schiffauerova, A. and Thomson,V,( 2006)," A Review of Research on Cost of Quality Models and Best practices", International Journal of Quality \& Reliability Management, Vol. 23, No. 4.

[38] Selami OZCAN, (2012 ),“An Empirical Research about Quality Cost Analysis and Its Impact on Managerial Decisions in Automotive Supplier Industry “, International Conference on Management, Applied and Social Sciences (ICMASS'2012) March 24-25, 2012 Dubai

[39] Shephered Nick A, (2002)," Integrating Cost of Quality into Performance Improvement Plants", Annual Quality Congress, Denver, vol. 56, No.1,

[40] Soo-Jin Cheah, (2011,), "Tracking Hidden Quality Costs in a Manufacturing Company: An Action Research", International Journal of Quality \& Reliability Management, Vol 28, No.4, pp 405-425.

[41] Sower, V.E., (2007), "Cost of Quality Usage and its Relationship to Quality System Maturity", International Journal of Quality \& Reliability Management, Vol.24, No.2, 121-140.

[42] Suresh Kumar Krishnan, (2006,), "Increasing the Visibility of Hidden Failure Costs", Measuring Business Excellence, Vol. 10 Iss: 4, pp.77 - 101

[43] Suresh Kumar Krishnan, Arawati Agus, Nooreha Husain, (2000), "Cost of quality: The hidden costs". Total Quality Management, Volume 11, Issue 4-6, 844-848.

[44] T. Nath, V.N.A. Naikan, B. Mohanty, (2003), "Implementation of Cost of Quality among Indian Industries: A Survey", Int. J. of Manufacturing Technology and Management , Vol.5, No.5/6 , pp.579-592.

[45] Teeravaraprug, "Quantification of Tangible and Intangible Quality Costs", Proceedings of the Fifth Asia Pacific Industrial Engineering and Management Systems Conference 2004

[46] Tsai, W.H., (1998), "Quality Cost Measurement under Activity-Based Costing", International Journal of Quality \& Reliability Management, Vol. 15 No. 7, pp. 719-52.

[47] Uyar, Ali. (2008), "An Exploratory Study on Quality Costs in Turkish Manufacturing Companies", International Journal of Quality \& Reliability Management, 25(6), 604-620.

[48] Weng, Ming-Chu ,( 2010), "Quality Cost Improvement Models Considering Fuzzy Goals", International Journal of Organizational Innovation (Online) > Vol. 2 , No. 4, April 2010

[49] Yang, C.C., (2008), "Improving the definition and quantification of quality costs", Total Quality Management, Vol. 19 No. 3, pp. 175-91.

[50] Zulnaidi Yaacup, (2010), "Quality Management as an Effective Strategy of Cost Savings", African Journal of Business Management, Vol.4 (9), pp 1844-1855. 